\title{
Biomonitoring the Health of Lake Mansar (Jammu), Using Phytoplankton
}

\author{
Assadullah Sheikh ${ }^{{ }^{*}} \cdot$ Deepika Slathia ${ }^{1}$ \\ ${ }^{1}$ Department Of Environmental Sciences, University of Jammu, Jammu, 180006. J\&K, India. \\ *Corresponding Author Email id: asad.rehm@gmail.com
}

Received: 17.11.2020; Revised: 15.02.2021; Accepted: 18.02.2021

(C)Society for Himalayan Action Research and Development

\begin{abstract}
Phytoplankton investigation of a sub-tropical Lake Mansar has revealed a total of 92 species belonging to Chlorophyceae (57 spp.), Bacillariophyceae (20 spp.), Cyanophyceae (11 spp.), Dinophyceae (2spp.) and Euglenophyceae (2 spp.). Perennial Chlorophyceae was recorded to be the most occurred group throughout the study period. Palmer algal genus and species pollution index was used to monitor the health of Mansar Lake. The total scores of 36 for algal genus and 16 for algal species have shown organic pollution of the lake. Thus, phytoplankton can be considered as good bio-indicator for assessing the health of the Lake. Present observations showed that the lake is a highly productive water body, facing pollution problems and is approaching towards eutrophication due to the presence of high number of pollution indicator species of algae. Conservation strategies of the lake must take cognizance to protect it from further deterioration.
\end{abstract}

Keywords: Palmer Index $\bullet$ Bioindicators $\bullet$ Organic Pollution $\bullet$ Eutrophication $\bullet$ Conservation

\section{Introduction}

Geometric increase in human population coupled with rapid urbanization, industrialization, technological advancement and agricultural development has deteriorated the pristine nature of inland water bodies viz. lakes, wetlands, rivers etc. (Ibrahim and Nafi, 2017). Water pollution problems always impact the biological setup of water body both qualitatively and quantitatively. Bioindicators are taxa or groups of organisms that depict the environmental health due to human activities or the disturbances of its biotic system (Singh and Sharma, 2003; Bisht et al. 2019). The important groups of organisms that have been used as environmental pollution indicators include bacteria, fungi, algae, protozoa, higher plants, macro-invertebrates and fish. The presence and absence of the indicator organisms reflects the conditions of aquatic environment. Algae are one of the excellent bioindicators of water quality changes due to their short life spans and quick response to conditions (Plafkin et al., 1993 and Singh and Sharma, 2018). Phytoplankton community is highly dynamic and has long been used as effective bioindicators of eutrophic water that is sensitive to environmental changes (Palmer, 1969; Chekryzheva, 2014 and Singh and Sharma, 2018). Species diversity and composition of the phytoplankton are used to assess the biological integrity of a water body (Sanet $e t a l$., 2006). Phytoplankton use as bioindicators of pollution has been studied by rating pollution tolerant algae in a water body by Palmer, (1969) who attempted to identify and prepare a list of genera and species of algae tolerant to organic pollution. He made a list of 60 genera and 80 species tolerant to organic pollution and formulated the pollution index scale for assessment of organic pollution. Palmer pollution index (Palmer, 1969) score of 20 or more represents the high organic pollution. Biomonitoring is therefore a useful alternative tool for assessing the ecological quality of aquatic ecosystems. No sincere effort has been made by earlier workers to study role of algae as indicators in the Mansar lake. Therefore, it was felt worthwhile to undertake study on the monitoring phytoplankton as bioindicator for determination of 
environmental health of Mansar wetland of Jammu, in Himalaya foothills.

\section{Materials and Methods}

\section{Study Area}

Mansar lake $\left(75^{\circ} 23^{\prime} 12^{\prime \prime} \mathrm{E}\right.$ and $32^{\circ} 48^{\prime} 58^{\prime \prime} \mathrm{N}$; elevation 666amsl) is heart shaped sub-oval, nondrainage type of fault basin is located in the Mansar village about $55 \mathrm{Km}$ east of Jammu city in District Samba (Fig. 1). Lake has surface area of about $0.58 \mathrm{~km}^{2}$, circumference of $3.294 \mathrm{~km}$ and maximum depth, length and width of $38.25 \mathrm{~m}$, $1204 \mathrm{~m}$ and 645m, respectively $(\mathrm{NIH}, 1999$; Chandrakiran and Sharma, 2011). Mansar lake is a closed basin situated in the hilly terrain surrounded by pine forest having cultivated fields and crematorium ground on the western bank, Nag temple, higher secondary school, bathing ghats and small market area towards the north-western side, pumping station and bus stand towards eastern side, habitation, guest house and market area towards south-eastern side and, Nag temple and Surinsar-Mansar Wildlife Sanctuary towards the southern side.

The present study on algal taxa was conducted from January 2014 to December 2015. Water samples from the littoral zone were collected on monthly basis from the Lake Mansar. 20 liters of water were filtered with the help of plankton net through a $55 \mathrm{~mm}$ mesh size bolting silk and was allowed to settle down. The samples were preserved with $4 \%$ formaldehyde solution and 1 $\mathrm{ml}$ of lugol's solution. The phytoplankton analysis was performed with an inverted microscope ( $\mathrm{Sr}$. Biological Olympus Microscope $\mathrm{CH}$ 20i) using $10 \times 15 \times 40 \times$ and $100 \times$ objectives. The identification of phytoplankton species has been done by consulting standard literature in the form of keys, books and works (Prescott, 1956; Edmondson, 1992; Needham and Needham, 1962; APHA, 2005 and Bellinger and Sigee, 2010).

Palmer (1969) proposed a pollution index based on algal genus and species used for rating the water sample as low or high organically polluted. The pollution tolerant genera and species of algae were recorded from the lake. A list of most tolerant genera and species as per the Palmer index (1969) were calculated. A pollution index factor was assigned to each genus and species to determine the pollution index status of the Mansar Lake.

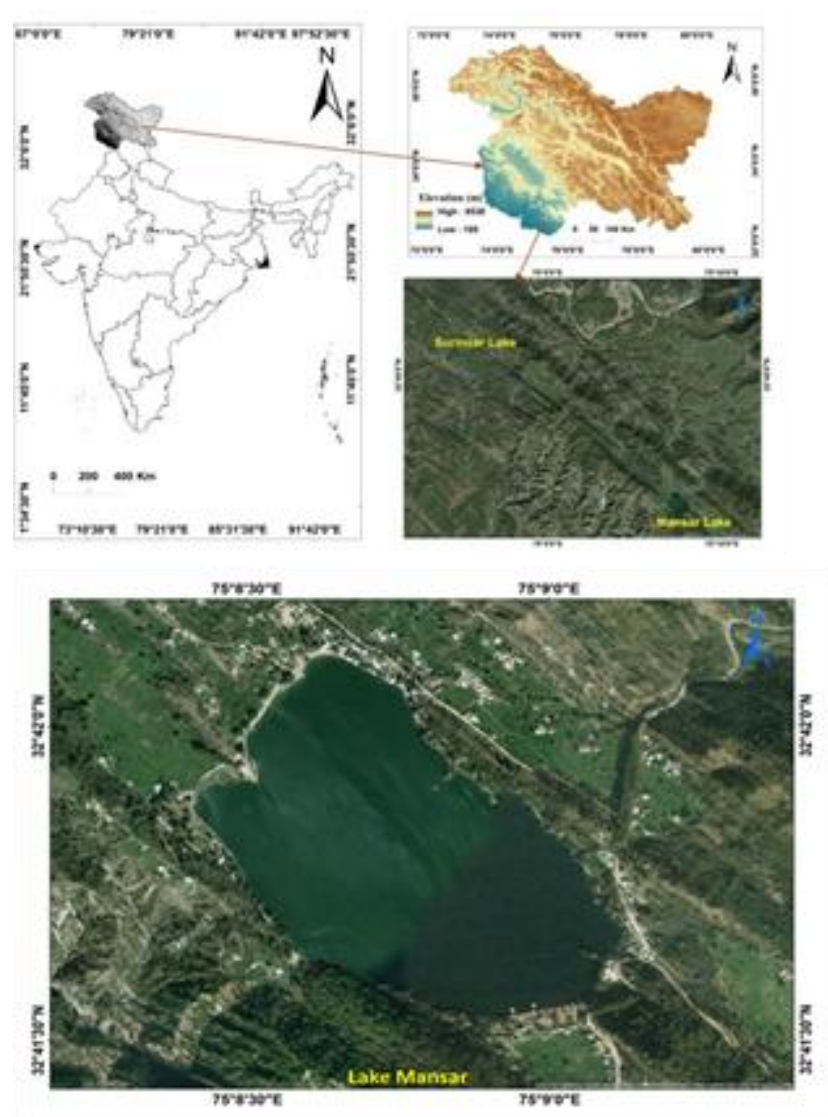

Fig. 1: Showing the location of the study arealake Mansar

\section{Results and Discussion \\ Qualitative composition}

The present study recorded 59 genera belonging to 92 species from Lake Mansar (Fig.2 \& Table-1). Qualitatively, among various classes, Chlorophyceae is represented by 57 species belonging to 32 genera, Bacillariophyceae 20 species belonging to 15 genera, Cyanophyceae by 11 species belonging to 9 genera, Euglenophyceae by 2 species of 2 genera and Dinophyceae by 2 species belonging to same genus.

Among the earlier studies carried out on this subtropical lake Mansar, Zutshi et al. (1980) reported 19 microphytic species belonging to Bacillariophyceae (9 spp.), Chlorophyceae (6 spp.), Cyanophyceae (3 spp.) and Dinophyceae (01 sp.); Sharma et al. (2007) reported 202 phytoplankton species belonging to 
Chlorophyceae (131 spp.), Bacillariophyceae and Cyanophyceae (each 31 spp.), Euglenophyceae (7 spp.) and Dinophyceae (02 spp.) and Chandrakiran et al. (2014) reported 33 microphytic species belonging to Chlorophyceae (13 spp.), Cyanophyceae (11 spp.) and Bacillariophyceae (09 spp.).

The qualitative distribution of phytoplankton in Lake Mansar during the present investigation revealed that the lake is approaching towards eutrophication due to the presence of high number of phytoplanktonic species belonging to Class Chlorophyceae, Bacillariophyceae and Cyanophyceae. Such dominance in normal conditions in lentic water bodies in tropics and subtropics has been reported by Kant (1985),
Sharma et al. (2007) and Chandrakiran et al. (2014).

The qualitative variations of phytoplankton classes in Mansar Lake indicated that these are richly manifested with phytoplankton. Seasonally, spring and post-monsoon phytoplankton high record may be attributed to high photoperiod and increase in water temperature. Whereas, short photoperiod and low temperature during winter may explain winter phytoplanktonic decline. Similar type of bimodal pattern in phytoplanktonic distribution have been recorded by Verma and Sharma (2009), Chandrakiran, et al. (2014) and Jindal et al. (2015). The qualitative studies from the littoral zones of Mansar lake reflect the idea that the waters in this wetlands is mesotrophic or between mesotrophic to eutrophic.

Table-1: Showing qualitative composition of phytoplankton taxa from Lake Mansar

\begin{tabular}{|c|c|c|c|}
\hline \multicolumn{2}{|c|}{ Class Chlorophyceae } & \multirow{3}{*}{$\begin{array}{l}34 \\
35\end{array}$} & \multirow{3}{*}{$\begin{array}{l}\text { Order Zygnematales } \\
\text { Closterium acerosum (Schr.) Ehr. } \\
\text { Closterium lenceolatum Kutz. }\end{array}$} \\
\hline S.No. & Name & & \\
\hline & Order Chlorococcales & & \\
\hline 1 & Ankistrodesmus convolutus Corda. & 36 & $\begin{array}{l}\text { Cosmarium awadhensis Prasad } \\
\text { Mehrotra }\end{array}$ \\
\hline 2 & Ankistrodesmus falcatus (Corda.) Rays & 37 & Cosmarium obtusatum Schmidle \\
\hline 3 & Actinastrum aciculare Playfair & 38 & Cosmarium phaselous Breb. \\
\hline 4 & Chlorella conglomerata (Artari) Oltmanns & 39 & Cosmarium subcranatum Nordst. \\
\hline 5 & Coelastrum microporum Naegalii & 40 & Cosmarium subtumidum Nordst.. \\
\hline 6 & Coelastrum phaselous Berb & 41 & Cosmarium ovatum Nordst.. \\
\hline 7 & Crucigenia quadrata Morren & 42 & $\begin{array}{l}\text { Cosmarium undulatum var. minutum } \\
\text { Corda. }\end{array}$ \\
\hline 8 & Crucigenia triangularis (Cord.) Schmidie & 43 & Plueraotacnium trabecula Naegalii \\
\hline 9 & Dictyosphaerium chlorelloides Naegalii & 44 & Penium minutum Cleve. \\
\hline 10 & Golenkinia radiata Chodat & 45 & Staurastrum natator W. \& West \\
\hline 11 & Hydrodictiyon reticulatum (Linn.) Legesh & 46 & $\begin{array}{l}\text { Staurastrum chaetoceras (Schröder) } \\
\text { G.M. }\end{array}$ \\
\hline 12 & Oocystis naegelii A.Braun & 47 & Spondylosium palnum (Wolle) West \\
\hline 13 & Pediastrum duplex Meyen & 48 & Mougeotia recurva (Hassael) De-toni \\
\hline 14 & Pediastrum ovatum (Ehr.) A. Braun & 49 & Mougeotia viridis (Kurtz) Wittrock \\
\hline 15 & Pediastrum simplex Mayen & 50 & Mougeotia floridana Trans \\
\hline 16 & Scenedesmus acuminatus (Lagerh.) Chodat & 51 & Spirogyra plena (West) Czurda \\
\hline 17 & Scenedesmus armatus (Cbod) Chodat & 52 & Spirogyra reticulina Randhawa \\
\hline 18 & Scenedesmus bijugatus (Turpin) Kuetzing & 53 & Spirogyra rivularis (Hassall) Rabenh. \\
\hline 19 & Scenedesmus dimorphus (Turpin) Kuetzing & 54 & Sirocladium kumaoense Randhawa \\
\hline 20 & $\begin{array}{l}\text { Scenedesmus periforatus Lemm. var. major } \\
\text { Turner }\end{array}$ & 55 & Sirogonium sticticum Kutz. \\
\hline 21 & Scenedesmus prismaticus Bruhl \& Biswas & 56 & Zygnema melanosporum Lagerh. \\
\hline
\end{tabular}




\begin{tabular}{|c|c|c|}
\hline 22 & $\begin{array}{l}\text { Scenedesmus platydiscus (G.M. Smith) } \\
\text { Chodat }\end{array}$ & Zygnema indicum Misra \\
\hline 23 & indica (Schroder) & Class Bacillariophyceae \\
\hline 24 & $\begin{array}{l}\text { Tetraedron incus (Teiling) G.M. Smith } \\
\text { Order Chaetophorales }\end{array}$ & $\begin{array}{l}\text { Order Pennales } \\
\text { Achnanthes lanceolata (Breb.) Grun. }\end{array}$ \\
\hline 25 & Coleochaete soluta (Breb.) Pringsch & $\begin{array}{l}\text { Amphora maharashtrensis Sorde \& } \\
\text { Kamat }\end{array}$ \\
\hline 26 & $\begin{array}{l}\text { Stigeoclonium farctum Breth } \\
\text { Order Cladophorales }\end{array}$ & $\begin{array}{l}\text { Amphora ovalis var. gracilis V. Hureck } \\
\text { Cocconeis placentula Ehr. }\end{array}$ \\
\hline 27 & $\begin{array}{l}\text { Cladophora glomerata (L.) Kutz. } \\
\text { Order Oedogoniales }\end{array}$ & $\begin{array}{l}\text { Cymbella bengalensis Grun. } \\
\text { Cymbella tumida Breb. }\end{array}$ \\
\hline 28 & Bulbochaete gigantea Pringsch & Diatoma vulgaris Bory \\
\hline 29 & $\begin{array}{l}\text { Oedogonium nodulosum Wittr. } \\
\text { Order Ulotrichales }\end{array}$ & $\begin{array}{l}\text { Fragilaria construens (Ehr.) Grun. } \\
\text { Gomphonema constrictum Ehr. }\end{array}$ \\
\hline 30 & Ulothrix elongatum Hodgetts & $\begin{array}{l}67 \text { Gomphonema lanceolatum (Her) F. } \\
\text { Turris }\end{array}$ \\
\hline 31 & $\begin{array}{l}\text { Ulothrix zonata (Weber and Mohr) Kutz. } \\
\text { Order Volvocales }\end{array}$ & $\begin{array}{l}68 \text { Gyrosigma acuminatum (Kutz.) Rabh. } \\
69 \text { Navicula cryptocephaloides Hustedt. }\end{array}$ \\
\hline 32 & Pandorina morum (Mull.) Bory & Navicula similis Krasske. \\
\hline 33 & Volvox globator (L.) Ehr. & $\begin{array}{l}\text { Chroococcus turgidus var. maximus } \\
\text { Nygaard }\end{array}$ \\
\hline 71 & Nitzschia ovalis Arnott & Lyngbya aestuarii Liebm. \\
\hline 72 & Nitzschia palea Kutz. & Merismopedia tenuissima Lemm. \\
\hline 73 & Pinnularia subcapitata Greg. & Microcystis aeruginosa Kutz. \\
\hline 74 & Surirella linearis W. Smith var. festechi Pant & Nostoc calcicola Breb. ex Born et Flah \\
\hline 75 & $\begin{array}{l}\text { Synedra acus var. radians (Kutz.) Hustedt } \\
\text { Order Centrales }\end{array}$ & $\begin{array}{l}87 \text { Oscillatoria curviceps Ag. ex Gomont } \\
88 \text { Spirulina gigantea Schmidle }\end{array}$ \\
\hline 76 & Cyclotella meneghiniana Kutz. & Class Euglenophyceae \\
\hline 77 & Melosira varians Ag. & 89 Euglena viridis Kelbs. \\
\hline & yanophyceae & $90 \quad$ Phacus curvicauda Swire \\
\hline 78 & Anabaena circinalis Rabneh ex Born et Flah & Class Dinophyceae \\
\hline 79 & Anabaena oryzae Fritsch & $91 \quad$ Glenodinium cinctum Ehr. \\
\hline 80 & $\begin{array}{l}\text { Calothrix fusca (Kutz.) Born et Flah } \\
\text { Chroococcus cohaerens (Breb) Nag }\end{array}$ & $\begin{array}{l}\text { Glenodinium kulezrynski (Wolsz.) } \\
\text { Schiller }\end{array}$ \\
\hline
\end{tabular}




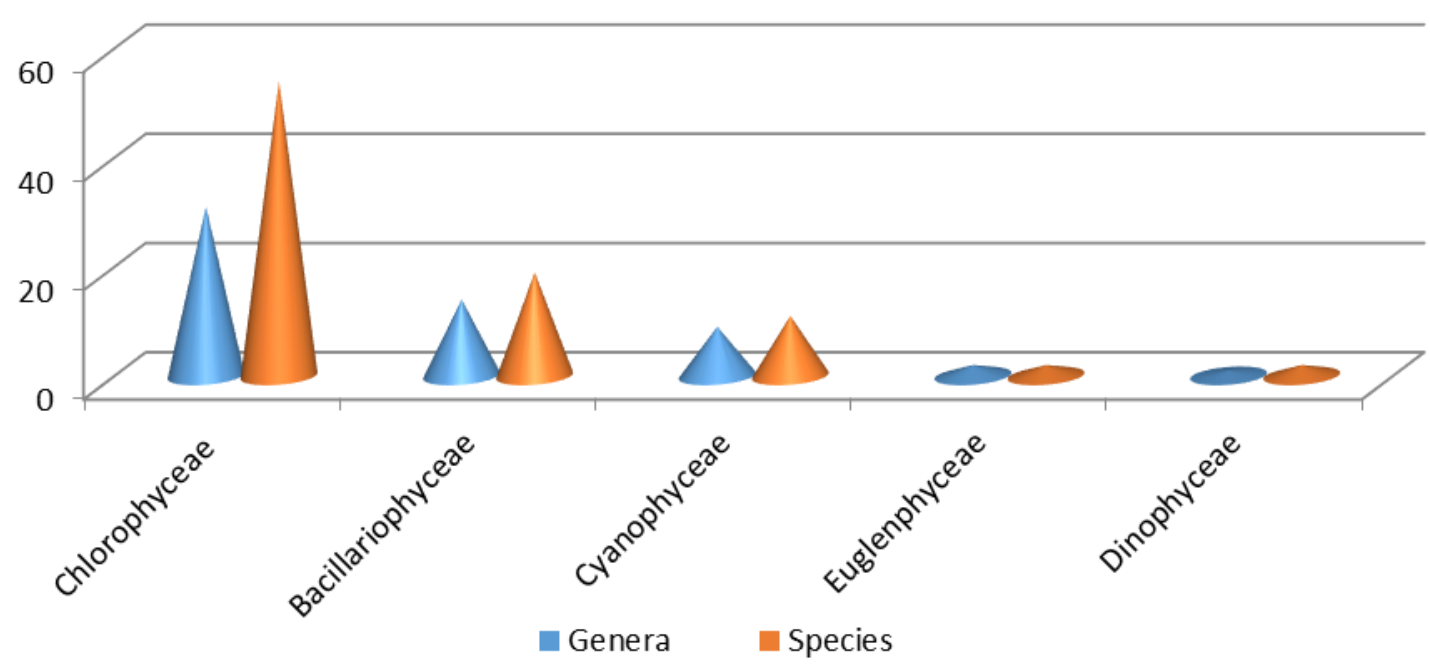

Fig.2: Graphical representation of various taxa in Lake Mansar.

\section{Palmer's organic pollution indices}

Palmer (1969) developed two algal pollution indices (genus and species) for use in rating of water samples with high pollution load. Two lists of organic pollution tolerant forms were preparedone containing 60 genera, the other 80 species. In the present study, both algal genus and species pollution index have been used to determine the status of Mansar lake. The calculated index has been compared with the algal pollution index scale for assessment of organic pollution of the water body (Table-2).

Table-2. Algal pollution index scale for assessment of organic pollution of the water body (Palmer, 1969)

\begin{tabular}{lll}
\hline S. No. & $\begin{array}{l}\text { Pollution } \\
\text { index }\end{array}$ & Pollution status \\
\hline $\mathbf{1}$ & $0-10$ & $\begin{array}{l}\text { Lack of organic } \\
\text { pollution }\end{array}$ \\
$\mathbf{2}$ & $10-15$ & $\begin{array}{l}\text { Moderate pollution } \\
\text { Probable high organic } \\
\text { pollution }\end{array}$ \\
$\mathbf{4}$ & $15-19$ & $\begin{array}{l}\text { Confirms high organic } \\
\text { pollution }\end{array}$ \\
\hline
\end{tabular}

Among the total algal genera reported as indicators of organic pollution by Palmer (1969), about 15 phytoplankton genera from the Lake Mansar have been recorded during the present study. The total algal genus pollution index score for Lake Mansar has been recorded as 36 which confirms high organic pollution of the lake (Table-3a). Among the algal species tolerant to organic pollution (Palmer, 1969) about 6 phytoplankton species from Lake Mansar have been recorded. The total algal species pollution index score for Mansar lake have been recorded as 16 indicating probable high organic pollution of the lake (Table-3b).

Patrick (1965) also documented the pollution tolerant status of genera Euglena and Oscillatoria and denoted them as indicators of eutrophication of the aquatic ecosystem. Presence of genus Scenedesmus indicates the eutrophic nature of the water body (Palmer, 1980). Algal genera viz. Chlorella, Scenedesmus, Pediastrum, Oscillatoria, Melosira, Navicula, Nitzschia, Gomphonema, Euglena indicates organic pollution of water body (Kshirsagar et al., 2012; Ganai and Parveen, 2014 and Jindal et al., 2014). Changes in algal diversity can be used to classify the quality of water (Kumar et al., 2012 and Kshirsagar (2013). Palmer (1969) reported that algae are important indicators of water pollution as it was evident during the present investigation. 
Table-3. Algal genus and species pollution index scale for Mansar lake (Palmer, 1969)

\begin{tabular}{|c|c|c|c|c|c|}
\hline \multicolumn{3}{|c|}{ (a) Algal Genus pollution index } & \multicolumn{3}{|c|}{ (b)-Algal species pollution index } \\
\hline Algal genus & $\begin{array}{l}\text { Pollution } \\
\text { index } \\
\text { (Palmer, } \\
1969 \text { ) }\end{array}$ & $\begin{array}{l}\text { Lake } \\
\text { Mansar } \\
(2014-15)\end{array}$ & Algal species & $\begin{array}{l}\text { Pollution } \\
\text { index } \\
\text { (Palmer, } \\
1969 \text { ) }\end{array}$ & $\begin{array}{l}\text { Lake } \\
\text { Mansar } \\
(2014-15)\end{array}$ \\
\hline Anacystis & 1 & 2 & Ankistrodesmus falcatus & 3 & 3 \\
\hline Ankistrodesmus & 2 & - & Arthrospira junneri & 3 & - \\
\hline Chlamydomonas & 4 & - & Chlorella vulgaris & 2 & - \\
\hline Chlorella & 3 & 3 & Cyclotella meneghianiana & 2 & - \\
\hline Closterium & 1 & 1 & Euglena viridis & 1 & 1 \\
\hline Cyclotella & 1 & 1 & E. acus & 6 & - \\
\hline Euglena & 5 & 5 & Gomphonema parculum & 1 & - \\
\hline Gomphonema & 1 & 1 & Melosira varians & 2 & - \\
\hline Lepocinclis & 1 & - & Navicula cryptocephala & 1 & 1 \\
\hline Melosira & 1 & 1 & Nitzschiza acicularis & 1 & - \\
\hline Micractinium & 1 & - & Nitzschia palea & 5 & 5 \\
\hline Navicula & 3 & 3 & Oscillatoria chlorine & 2 & - \\
\hline Nitzschia & 3 & 3 & O. limosa & 4 & - \\
\hline Oscillatoria & 5 & 5 & O. putrid & 1 & - \\
\hline Pandorina & 1 & 1 & O. princeps & 1 & - \\
\hline Phacus & 2 & 2 & O. tenuis & 4 & - \\
\hline Phormidium & 1 & - & Pandorina morum & 3 & 3 \\
\hline Scenedesmus & 4 & 4 & $\begin{array}{l}\text { Scenedesmus } \\
\text { quadricauda }\end{array}$ & 4 & - \\
\hline Stigeoclonium & 2 & 2 & Stigeoclonium tenиe & 3 & - \\
\hline Synedra & 2 & 2 & Synedra ulna & 3 & 3 \\
\hline Total & 44 & 36 & Total & 52 & 16 \\
\hline
\end{tabular}

\section{Conclusion}

Thus it can be concluded from the present study that palmer pollution index has shown high organic pollution in the Lake Mansar as algae are reliable indicators of water pollution. Algal genus pollution index score for Lake Mansar has been found as 36 which confirms high organic pollution of the lake and algal species pollution index score for Mansar lake have been recorded as 16 indicating probable high organic pollution of the lake. Change in diversity of algal communities can be used to determine and classify the water quality of lake. The study recommends the formulation of sustainable management plan and its implementation in order to preserve Mansar lake. Therefore to conserve it from further deterioration there is a need for regular monitoring. 


\section{Acknowledgements}

UGC, New Delhi, is acknowledged for providing Fellowship to Dr. Assadullah Sheikh. Necessary facilities provided by Head, Department of Environmental Sciences, University of Jammu, Jammu, are gratefully acknowledged.

\section{References}

APHA (2005) Standard methods for examination of water and wastewater. American Public Health Association, WWA, Washington, D.C.

Bellinger E G and Sigee D C (2010). Fresh water algae identification and use as bioindicators. Wiley Blackwell. pp: 1-138

Bisht K L, Dobriyal AK and Singh H R (2019). A note on the ecosystem health of a glacier-fed stream Pinder from Chamoli Garhwal, Uttarakhand, J. Mountain Res. 14(2): 9-17

Chandrakiran and Sharma K K (2011). Impact of sediment characteristics on the benthic communities of Lake Mansar. Jammu. Ph.D. Thesis, Deptt. of Zoology, University of Jammu.

Chandrakiran, Sharma, KK and Sharma R (2014). Phytoplankton community response to changing physico-chemical environment of subtropical lake Mansar, India. International Journal of Biosciences, 4(11): 95-103.

Edmondson W T (1992). Freshwater biology. $2^{\text {nd }}$ ed. John Wiley \& Sons, New York, U.S.A., 1959.

Ganai A H and Parveen S (2014). Effect of physico-chemical conditions on the structure and composition of the phytoplankton community in Wular Lake at Lankrishipora, Kashmir. Intl J Bio. Cons., 6(1): 71-84.

Ibrahim S and Nafi S A (2017). Phytoplankton as indicators of water quality in Thomas Dam, Dambatta, Kano State, Nigeria. Dutse J Pure Appl. Sc., 3(1): 119-133.

Jindal R, Thakura R K, Singh U B and Ahluwalia A S (2015). Phytoplankton dynamics and species diversity in a shallow eutrophic, natural mid-altitude lake in Himachal
Pradesh (India). Role of physicochemical factors. Chemistry and Ecology, 30(4): 328338.

Kant S (1985). Algae as indicators of organic pollution. In: Advances in Applied Phycology. (Ed:Shukla AC and Pandey S N). Int. Soc. Environ., 87-91.

Kshirsagar A D (2013). Use of algae as a bioindicator to determine water quality of River Mula from Pune City, Maharashtra (India). Uni J Env. Res.Tech., 3(1): 79-85.

Kshirsagar A D, Ahire M L and Gunale V R (2012). Phytoplankton diversity related to pollution from Mula river at Pune City. Terr. Aqu Env. Toxico., 6(2): 136-142

Kumar P, Wanganeo A, Fozia S and Wanganeo R (2012). Limnological study on two high altitude Himalayan ponds, Badrinath, Uttarakhand. Int J Ecos, 2(5): 103-111.

Needham J G and Needham P R (1962). A guide to the study of fresh water biology. Publishers-Holden -Day, San Francisco, U.S.A. pp: 107.

NIH (1999) Report on water quality monitoring and evaluation of Mansar lake, Udhampur district, (J\&K).

Palmer C M (1969). Composite rating of algae tolerating organic pollution. $J$ Phyc, 5: 78-82

Palmer C M (1980). Algae and water pollution. Castle House Publishers Ltd., England.

Patrick R (1965). Algae as indicator of pollution. A biological problem in water pollution, $3^{\text {rd }}$ seminar 1962. Robt. A. Taft. Sanitary Engineering Center, Publ. Hlth. Serv. Publs. Washington. pp: 223-232.

Plafkin J L, Barbour M T, Porter K D, Gross S K, and Hughes R M (1989). Rapid Assessment Protocols for Use in Streams \& Rivers: Benthic Macro invertebrates \& Fish. EPA: Washington, D.C. Rosenberg, D.M., V.H.Resh (eds). 1993. Freshwater Biomonitoring \& Benthic Macroinvertebrates. Chapman \& Hall, New York.

Prescott G W, (1956). A guide to the literature on ecology and life histories of algae. The Bot Rev, 22: 167-240. 
Sanet J V, JonathonT, Carin VG and Annelise G (2006). Easy identification of the common fresh algae: A guide for the identification of microscopic algae in southern fresh waters, North West University, Potchefsroom, Pretoria. pp: 31- 44.

Sharma K K, Mohan C and Zubair S M (2007). Phytoplankton diversity in the Lake Mansar, Jammu. J Res Dev., 7: 141-148.

Singh S and Sharma R C (2018). Monitoring of algal taxa as bioindicator for assessing the health of the high altitude wetland, Dodi Tal, Garhwal Himalaya, India. Int. J Fish Aqu. Stud., 6(3): 128-133.

Zutshi D P, Subla B A, Khan M A and Wanganeo A (1980). Comparative limnology of nine lakes of Jammu and Kashmir Himalayas (India). Hydrobiologia., 72: 101-112. 